\title{
Die letterlike vertolking van metaforiese taal in Josua 10:12-14
}

\author{
A P B Breytenbach \\ Departement Ou-Testmentiese Wetenskap \\ Universiteit van Pretoria
}

\begin{abstract}
The literal understanding of metaphoric language in Joshua 10:12-14

In this article the well-known passage in Joshua 10:12-14 is critically investigated within the context of the pericope of Joshua 10. A literary critical investigation shows, inter alia, that the oldest version of the pericope probably was a heroic saga of Joshua's campaign, with the miraculous intervention of YHWH having been “written into" the narrative at a later stage. During the latter process a poetic fragment, the original of which is lost to us, was interpreted literally, thus creating a miracle account. This miracle account serves the main focus of the pericope: YHWH alone makes possible the impossible for his people.
\end{abstract}

\section{INLEIDING}

Wanneer die navorsingsgeskiedenis van die bekende woorde in Josua 10:12-14 nagegaan word, is dit duidelik dat daar geen eenstemmigheid is oor die geskiedenis en die interpretasie van die teks nie. Die interpretasies wat in kommentare en tydskrifartikels gebied word, lê oor 'n wye spektrum van moontlikhede. Dit wissel van 'n naïewe "dit het werklik so gebeur en daarom moet jy elke woord glo net soos dit daar geskryf staan" tot 'n radikale rasionalistiese verwerping van die teks as die oorblyfsel van 'n mitiese

\footnotetext{
${ }^{1}$ Dié dag toe die Here die Amoriete in die mag van die Israeliete gegee het, het Josua die Here om hulp gevra. Ten aanhore van Israel het hy gesê: "Son staan stil in Gibeon, en maan, staan stil in Ajalonlaagte!" Die son het stilgestaan, die maan het nie geroer nie totdat Israel sy vyande verslaan het. Dit staan so geskrywe in die Boek van die Opregte. Die son het halfpad in die hemel bly staan. Byna 'n volle dag was hy nie haastig om onder te gaan nie (Josua 10:12-13; Nuwe Afrikaanse Vertaling).
} 
vertelling wat vir die moderne mens niks te sê het nie. Die verskillende standpunte kan vanuit 'n bepaalde hoek in twee hoofstrome ingedeel word, naamlik dié van outeurs wat die gegewens in die teks as basis neem en dit probeer verklaar aan die hand van natuurverskynsels; en dié van outeurs wat 'n literêr-teologiese oplossing vir die klaarblyklik bonatuurlike vertelde gebeure aan die hand doen.

Die bedoeling van hierdie artikel is om die eie aard van die teks waarbinne hierdie eenheid (naamlik Jos 10:12-14) funksioneer, na te gaan en dan binne hierdie konteks te vra na die funksie van die eenheid. Dit is egter nodig om vooraf enkele opmerkings te mak oor die verskillende benaderings wat tot dusver die navorsing van die eenheid gekenmerk het.

\section{2. 'N KORT OORSIG VAN VERSKILLENDE VERKLARINGS}

Op die Suid-Afrikaanse akademiese toneel bied H A J Kruger die beste samevatting van verskillende standpunte oor Jos 10:12-14 (Kruger 2000). Hy bied dit aan onder die rubrieke Explanations based on meteorological phenomena; Explanations in terms of astronomy; Explanations based on religion, mythology and/or omens and military strategy, en A theological view: divine war. Onder die eerste twee rubrieke hanteer hy die standpunte wat die verwysing na die stilstaan van die son by Gibeon verklaar as

- 'n (onnatuurlike) haelstorm in die middel van die somer in Palestina (vgl Jos 10:11);

- ligrefraksie wat as gevolg van baie koue winterlug die illusie geskep het dat die son nog skyn nadat dit al onder was;

- 'n meteorietreën in die veertiende eeu voor Christus (na aanleiding van Jos 10:11a waar daar letterlik in die Hebreeus staan dat JHWH groot klippe uit die lug/hemel op die vyande gegooi het);

- 'n totale sonsverduistering (Sawyer, soos aangehaal deur Butler [1983:112], het selfs die presiese tyd aangedui, naamlik van 12:40 tot 12:44 op 30 September $1131 \mathrm{vC}$.). 
Onder die laaste twee rubrieke hanteer hy onder andere die standpunte wat die verwysings na die stilstaan van die son verklaar as

- 'n polemiese konflik tussen JHWH en sekere Kanaänitiese gode (naamlik die son- en die maangod);

- 'n identifisering van JHWH met die songod vir wie daar 'n kultus was in Gibeon;

- 'n gebed van Josua dat die twee hemelliggame in 'n gunstige posisie sal wees volgens die astronomiese voorspellings van daardie tyd;

- 'n neerslag van die motief van die heilige oorlog waarin die godheid op 'n dramatiese wyse in gevegte ingryp en die uitslag bepaal.

Kruger self maak nie 'n besliste keuse tussen die spektrum van standpunte nie. Hy vat die saak soos volg saam (Kruger 2000:149):

[I]n explanations of the passage in terms of the idea of divine war, supported by ancient Near Eastern literature and iconography, features of myth and omens used for military strategy, seem to prevail. These areas of study have been integrated with a theological view of the passage. However, other possible interpretations of the passage related to the latter ideas still need to be investigated.

In 'n ander bydrae (Kruger 1999), werk Kruger dan met die moontlikheid dat die voorstelling van die uitspansel as 'n (boonste) meulsteen en die katastrofiese gevolge wat plaasvind wanneer dié meulsteen tot stilstand kom, die mitiese agtergrond is van 'n vertelling waarin dit eintlik gaan oor JHWH as die "divine warrior". Kruger beweeg daarmee in 'n bepaalde rigting waarmee ek my nie kan vereenselwig nie. Ek is nie oortuig daarvan dat daar voldoende bewyse is vir die voorkoms van die meulsteenmotief in Wes-Semitiese mitologie nie. Daarby is dit 'n wesenlike vraag of die teks in Jos 10 'n mitologiese vraagstelling van die eksegeet vereis. Dit is moontlik dat die poëtiese 
aanhaling in Jos 10:12b-13a teen 'n mitiese agtergrond verstaan moet word, maar dit is (soos hopelik verder in hierdie artikel sal blyk) deel van die voorgeskiedenis van die stukkie poësie - iets waartoe ons in elk geval nie toegang het nie. Ek meen dus dat Kruger in sy konstruk nie die teksaanbod as sodanig krities genoeg hanteer nie.

Pogings om die vertelling in Jos 10:12-14 te verklaar as die weergawe van 'n werklike historiese gebeure, verskil nie wesenlik van die naïewe standpunt dat elke woord soos dit daar staan, letterlik geneem moet word nie. Die enigste verskil is dat die verklarings wat die vertelde gebeure verbind met natuurverskynsels soos 'n meteorietreën of sonsverduistering, kwasiewetenskaplik is. Hieroor het Steuernagel (1923:248) reeds gesê: "Alle Versuche, es rationalistisch zu erklären oder ihm eine mit dem Kopernikanischen Weltsystem harmonierende Fassung $\mathrm{zu}$ geben, sind a limine abzuweisen." Die opmerking van Beek (1981:118), "Het is op zichzelf boeiend (en soms lachwekkend), een overzicht van de exegetische pogingen te lezen," vat die indruk wat die kwasiewetenskaplike verklarings by 'n mens laat, nogal goed saam.

\section{DIE TEKSAANBOD}

Die Hebreeuse teks van Jos 10:1-43 lewer verskillende probleme op ten opsigte van sy koherensie as ' $\mathrm{n}$ vertelling. Die volgende probleme kan as die belangrikste aangedui word:

- Die vyf stede wat die koalisie vorm en teen wie Josua met sy leër optrek (naamlik Jerusalem, Hebron, Jarmut, Lakis en Eglon, vgl vs 1-27) verskil merkwaardig genoeg van die lys van ses stede wat deur Josua in 'n klaarblyklike strafekspedisie daarna ingeneem word (Makkeda, Libna, Lakis, Eglon, Hebron en Debir, vgl vs 28-39).

- In die optrede teen die vyf bondgenote is Debir die naam van 'n koning, terwyl dit in die optrede teen die stede die naam van 'n stad is ( $v g l$ vs 3 en 38-39).

- In die een eenheid (vs 22-27) word die koning van Hebron by die grot van Makkeda doodgemaak en in die volgende eenheid (vs 28-39) word die koning van Hebron in Hebron self doodgemaak. 
- In vs 15 word die eenheid wat gaan oor die optrede teen die koalisie afgesluit met die woorde: "Daarna is Josua, en die hele Israel saam met hom, terug na die kamp toe in Gilgal.” In die eenheid wat onmiddellik daarna volg (vs 16-21), is Josua en die Israeliete egter nog steeds aktief besig met die agtervolging, en keer hulle terug na 'n kamp in Makkeda (vgl ook Fritz 1994:113). Opvallend genoeg word vs 15 woordeliks herhaal in vs 43 as afsluiting van die hele perikoop.

- In die eenheid vs 16-21 is dit onduidelik waar Josua hom bevind: Aanvanklik kry 'n mens die indruk dat hy nie by die manskappe is nie en slegs bevele vir hulle deurstuur (vs 16-19). En dan volg vs 20 en 21 wat lees: "Nadat Josua en die Israeliete die groot slagting onder hulle aangerig het tot die laaste man toe (die wat vrygekom het onder hulle het na die versterkte stede gevlug) het al die manskappe teruggekeer na die kamp, na Josua (sic!) in Makkeda ...."

- In vs 10 is JHWH die grammatikale subjek van 'n reeks handelinge wat duidelik by Josua tuishoort: "En JHWH het hulle in verwarring gebring voor die Israeliete en Hy het 'n groot slagting onder hulle aangerig in Gibeon en hulle agtervolg deur die pas na Bet-Goron en hulle kafgeloop tot by Aseka en tot by Makkeda." Die meeste vertalings en kommentare beskou Josua of Israel (Noth 1971:63v) as die subjek van die handelinge wat volg nadat die vyand in verwarring gebring is. Die Septuaginta het die teks soos dit daar staan egter korrek geïnterpreteer en Kupıos as die subjek van al die handelinge verstaan. Soggin (1972:117), Boling (1982:273v), Butler (1983:107) en Fritz (1994:108 en 111) verstaan dit ook so.

- Dit is onduidelik wie die spreker en wie die aangesprokene is in vs 12. Sommige kommentatore meen dat JHWH die son en die maan aanspreek wanneer daar staan: "En hy het voor die (oë van die) Israeliete gesê: 'Son staan stil in Gibeon en maan in die Ajalonlaagte ...." Ander meen weer dat Josua die spreker is wat met JHWH praat. Uit wat volg in vs 13-14 is dit duidelik dat die bedoeling van die finale outeur sonder enige twyfel is dat Josua hierdie woorde tot JHWH gerig het. Die lastigheid bly egter dat die son en maan, en nie JHWH nie, in die poëtiese deel aangespreek word. 
Daar is ook nog ander oneffenhede in die teks van Josua 10 soos byvoorbeeld dat "en tot by Makkeda" in vs 10 onvermydelik die indruk wek van 'n byvoeging nadat daar reeds gesê is dat die agtervolging tot by Aseka volgehou is.

Uit die voorafgaande is dit duidelik dat die teksaanbod van Josua 10:1-43 nie koherent is nie, en dat die vertelling soos dit tans daar uitsien, sonder twyfel saamgestel is uit verskillende vertellings of tekstradisies. Pogings van kommentatore om die oneffenhede in die Hebreeuse teks toe te skryf aan tekskorrupsie en op grond van die Septuaginta die teks te verbeter (bv Boling 1982:275-277), is nie oortuigend nie. So word daar byvoorbeeld beweer dat die dubbele verwysing na die dood van die koning van Hebron in die Masoretiese teks (vs 26 en 37) aan tekskorrupsie toegeskryf moet word, aangesien die Septuaginta nie so ' $n$ verwysing bevat in vs 37 nie. Steuernagel het egter al daarop gewys dat die argument nie opgaan nie: "Freilich fehlen die Worte ואת מלכה (v 37) in LXX; es ist jedoch leichter erklärlich, dass LXX die Worte mit Rücksicht auf v. 26 ausliess, als dass sie trotz v.26 nachträglich beigefügt wären” (Steuernagel 1923:245). Dit geld vir feitlik al die gevalle waar die Septuaginta sogenaamd 'n "beter" lesing het as die Masoretiese teks. Dit is trouens 'n normale tendens in feitlik alle vertalings om oneffenhede so ver as moontlik weg te vertaal of minstens te versag. Die Septuaginta toon ook 'n verduidelikende tendens in die vertaling. So byvoorbeeld word' Inoous in 'n paar gevalle bygevoeg waar dit uit die verband afgelei kan word dat Josua die subjek van die handeling is, maar waar sy naam in die Masoretiese teks ontbreek. Dieselfde geld ook in die geval van Jos 10:12 waar die Septuaginta in die plek van לעיני ישראל die

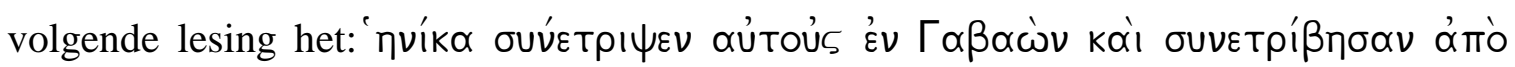

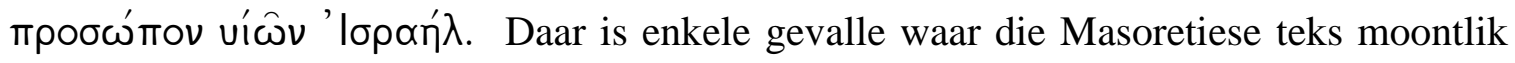
met ' $n$ woord of sinsnede uitgebrei is in die latere ontwikkelingsgeskiedenis van die teks. 'n Voorbeeld hiervan is waarskynlik die verwysing na die ספר הישר wat in die Septuaginta ontbreek. Dit is egter uiters onwaarskynlik dat kleiner aanpassings wat later in die Masoretiese teks gemaak is, teenstrydig sou wees met die inhoud wat reeds daar staan, en dat oneffenhede op dié wyse veroorsaak is.

Fritz (1994:1-3) moet gelyk gegee word wanneer hy argumenteer dat die afwykende lesings in die Septuaginta (behalwe in die geval van plekname) nie 'n ouer teks as die Masoretiese teks veronderstel nie, maar dat dit grootliks te wyte is aan styl, interpreterende vertaling en byvoegings. Die teks van die boek Josua het vir 'n lang tyd 
klaarblyklik nie as "kanoniek" gegeld nie, maar is steeds verklarend en andersins uitgebrei - 'n proses wat in die Vorlage van die Septuaginta voortgesit is (vgl ook Butler 1983:117). Fritz vat die saak goed saam wanneer hy sê die Septuaginta "bietet ... insgesamt doch keine besseren oder älteren Text als die masoretische Fassung, sondern eine weiter entwickelte Textform" (Fritz 1994:2).

\section{MOONTLIKE VERKLARINGS VIR DIE ONEFFENHEDE}

'n Noukeurige studie van die Hebreeuse teks toon dat, met enkele uitsonderings, die oneffenhede hoofsaaklik tussen die verskillende eenhede van die perikoop bestaan. Die verskil in die name van die stede, die verskil in die gebruik van die naam Debir, die teenstrydige vertellings oor die dood van die koning van Hebron en die probleem van die slot van die vertelling in vs 15 wat opgevolg word deur 'n eenheid waarin die agtervolging nog in swang is, is kennelik verskille tussen kleiner eenhede in die teks, naamlik vs 1-15, 16-27, 28-39 en 40-43.

Jos 10:1-15 vorm 'n afgeronde eenheid wat handel oor 'n veldslag van Josua teen die koalisie van vyf Kanaänitiese vorste wat Gibeon beleër, die stad met wie die Israeliete 'n ooreenkoms aangegaan het. Die eenheid begin met die vorming van die koalisie en eindig, ná 'n suksesvolle veldtog, met die terugkeer van Josua na die basis waarvandaan hy aanvanklik opgeruk het. ${ }^{2}$ Opvallend genoeg duik die oneffenhede wat binne hierdie eenheid voorkom, op in twee gevalle waar JHWH handelend of sprekend ingevoer word in die vertelling, naamlik vs 10 en vs 12-14: Soos reeds aangedui is die feit dat JHWH die grammatikale subjek is van die handelinge in vs 10 'n probleem; en in vs 12 is die vraag na die spreker en die aangesprokene 'n probleem. 'n Noukeurige ondersoek bring aan die lig dat 'n koherente vertelling oor Josua se optrede teen die vyf konings die raamwerk vorm waarin die handelinge en woorde van JHWH klaarblyklik ingevoeg is. Die

\footnotetext{
2 Die kommentatore wat meen dat Jos 10:15 uit 10:43 oorgeneem is (Fritz 1994:112), kan geen logiese argumente aanvoer vir dié standpunt nie.
} 
volgende vertaling wat die Hebreeuse teks redelik op die voet volg, maar wat die optrede en woorde van JHWH in vierkantige hakies plaas en in kursief druk, illustreer die saak: ${ }^{3}$

$1{ }^{1}$ Toe die koning van Jerusalem hoor dat Josua Ai ingeneem en haar met die banvloek getref het (soos wat hy met Jerigo en haar koning gedoen het, so het hy met Ai en haar koning gedoen) en dat die inwoners van Gibeon vrede gemaak het met Israel en tussen hulle bly, ${ }^{2}$ het hulle baie benoud geraak, want Gibeon was 'n groot stad, soos een van die stadstate (dit was selfs groter as Ai) en al haar soldate was dapper vegters. ${ }^{3}$ Adonisedek, die koning van Jerusalem het 'n boodskap gestuur na Hoham, die koning van Hebron, en na Piram, die koning van Jarmut, en na Jafia, die koning van Lakis, en na Debir, die koning van Eglon om vir hulle te sê: ${ }^{4}$ "Trek op na my toe en help my dat ons Gibeon kan aanval want sy het vrede gemaak met Josua en met die Israeliete." 5 Die vyf konings van die Amoriete, naamlik die koning van Jerusalem, die koning van Hebron, die koning van Jarmut, die koning van Lakis en die koning van Eglon, het saamgekom en opgetrek, hulle met al hulle troepe. Hulle het Gibeon beleër en teen haar geveg. ${ }^{6}$ Die manne van Gibeon het na Josua, na die kamp in Gilgal 'n boodskap gestuur: "Moet u tog nie aan u dienaars onttrek nie. Kom gou na ons toe en red ons en help ons, want al die konings van die Amoriete wat op die bergland woon, het teen ons saamgetrek." ${ }^{7}$ Josua het toe van Gilgal af opgetrek, hy en al die soldate by hom en al die geoefende vegters. ${ }^{8}$ En JHWH het vir Josua gesê: "Moenie vir hulle bang wees nie want Ek gee hulle in jou hand. Nie een van hulle sal voor jou standhou nie."] ${ }^{9}$ En Josua het hulle oorval nadat hy dwarsdeur die nag van Gilgal af getrek het. $\left[{ }^{10}\right.$ En JHWH het hulle in verwarring gebring voor Israel.] En hy het 'n groot slagting onder hulle aangerig by Gibeon en hulle agtervolg op die pad wat na Bet-Horon toe opgaan, en hulle neergeslaan tot by Aseka (en tot by Makkeda). $\left[{ }^{11}\right.$ En tydens hulle vlug voor Israel-hulle was op

\footnotetext{
${ }^{3}$ Steuernagel (1923:245-248) het iets soortgelyks gedoen, maar ander resultate bereik omdat hy nog vanuit die paradigma van die JEDP-bronneteorie werk. Görg (1991) meen dat Josua 10:1-10, 12-13, 17-20, 22-24 en 26-27 voor-Deuteronomiese oorlewering verteenwoordig. Hy beredeneer sy redaksie-kritiese onderverdeling van die hoofstuk egter nie behoorlik nie. Fritz (1994:107-113) kom, in aansluiting by Noth (1971:56-67) ook tot ander resultate. Hy skryf (met uitsondering van vs $1 b, 2 b, 7 b, 9 b$ en 11) die hele eenheid toe aan die Deuteronomistiese redaktor DtrH wat onder andere die name van die stede in Jos 10:13 uit die lys in Jos 12:10-13 sou kry. Daar is egter leemtes in Fritz se analise, soos byvoorbeeld dat die naam Debir nié as pleknaam in vs 1-15 voorkom nie, asook die probleem dat die name van die konings klaarblyklik uit 'n ander oorlewering as die lyste in Jos 12 kom.
} 
die afdraande van Bet-Horon - het JHWH groot haelstene uit die lug op hulle gegooi tot by Aseka. En die wat dood is deur die hael, was meer as die wat die Israeliete doodgemaak het met die swaard. ${ }^{12}$ Toe het Josua met JHWH gepraat op die dag wat JHWH die Amoriete aan die Israeliete oorgegee het. En hy het voor die ö̈ van Israel gesê:

\footnotetext{
"Son staan stil in Gibeon en maan in Ajalonlaagte."

${ }^{13}$ En die son het stilgestaan en die maan het gestaan totdat die volk wraak geneem het op sy vyande.
}

Staan dit nie geskrywe in die Boek van Jashar nie? Ja die son het gestaan in die middel van die lug en vir omtrent 'n dag was hy nie haastig om onder te gaan nie. ${ }^{14}$ En daar was nie nog so 'n dag voor hom of na hom nie, dat JHWH geluister het na die stem van 'n man nie. Ja JHWH het vir Israel geveg. ${ }^{15}$ En Josua en die hele Israel saam met hom het teruggegaan na die kamp in Gilgal.

Die afleiding wat uit die voorafgaande gemaak kan word, is dat 'n vertelling oor Josua se hulp aan die Gibeoniete in die styl van 'n heldesage ${ }^{4}$ as raamvertelling gedien het vir die (latere) invoeging van JHWH se optrede (contra Noth 1971:61). Die bedoeling van die latere invoeging is baie duidelik. Dit is naamlik om die lesers tot die oortuiging te bring dat die oorwinning waarvan die heldeverhaal vertel, volledig aan JHWH te danke is. Hy gee Josua die moed om die taak aan te pak (vs 8); Hy veroorsaak die verwarring in die geledere van die vyand (vs 10a) en Hy sorg deur bonatuurlike ingryping dat die gevegte in 'n klinkende oorwinning vir die Israeliete eindig. Trouens, JHWH is direk verantwoordelik vir die dood van 'n groter getal van die vyand as die Israeliete. Dit is binne hierdie verband wat die verwysing na die son en maan wat stilgestaan het, geïnterpreteer moet word. Hierop kom ek later terug.

Jos 10:16-27 is in die finale teks klaarblyklik bedoel as 'n soort terugskouing op gebeure wat voor die terugkeer na Gilgal (vs 15) plaasgevind het. Dit is egter duidelik

\footnotetext{
4 Alhoewel Fritz nie die aangeduide verse as 'n raamvertelling en daarom as 'n sage beskou nie, is die kenmerkende eienskappe wat hy aan 'n sage toeskryf, hier van toepassing, naamlik "die episodenhafte Darstellung, die Beschränkung der Anzahl handelnder Personen, die Gradlinigkeit in der Durchfürung und die Verhaftung an einem namentlich genannten Ort" (Fritz 1994:5).
} 
dat hierdie eenheid wat oorspronklik 'n selfstandige oorlewering was (vgl Gray 1967: 106; Fritz 1994:5; Nelson 1997:138), nie op 'n geslaagde wyse by die vertelling in vs 115 aansluit nie. Butler (1983:111 en 116) is korrek wanneer hy stel dat die naam Makkeda aan die einde van vs 10 klaarblyklik bygevoeg is om die verbinding tussen die eenhede Jos 10:1-15 en 16-27 te versterk (so ook Hertzberg 1973:74; Fritz 1994:109v; Nelson 1997:139 en andere). Die spesifieke vermelding van die vyf konings (vs 23) bind ook die eenheid aan die oorspronklike raamvertelling in vs 1-15. Die oënskynlike teëspraak in vs 20, naamlik dat Josua en die Israeliete die vyande totaal vernietig het ( $\mathrm{vgl}$ (עד־תמם (עם die maar dat dié onder hulle wat vrygekom het, in die versterkte stede ingevlug het, kan verklaar word as 'n poging om die daaropvolgende (oorspronklik onafhanklike) eenheid (vs 28-39) voor te berei (Fritz 1994:113). Die nate van die redaksionele byvoegings is verder sigbaar in die verskille wat met die voorafgaande eenheid uitgewys is, asook die onverwagse terugkeer na die vyf konings en hulle lot in die vertelling. Jos 10:16-27 was waarskynlik oorspronklik 'n soort etiologiese verhaal wat die teenwoordigheid van die groot klippe en moontlik ook vyf bome voor die grot by Makkeda verklaar het (Fritz 1994:5 en 109v). In sy huidige vorm dien dit egter as 'n voorbeeld van die karakter Josua se nougesette uitvoering van die voorskrifte van die Deuteronomistiese wet en die sukses wat dit meebring ( $\mathrm{vgl}$ in hierdie verband Deut 20:16; asook Jos 7 \& 8:1-29; vgl ook Deut 21:22-23 vir die mededeling dat die konings se lyke teen sononder afgehaal is van die pale waaraan hulle opgehang is). Op grond van tendense in die res van die boek Josua kan aanvaar word dat die figuur van Josua nie so prominent was in die oorspronklike etiologiese oorlewering nie. In die huidige vertelling word hy egter tot so 'n mate in die verhaal ingeskryf dat hy in Makkeda is (vgl die posisionering van die karakter in vs 16-19 en 21) maar tegelyk ook deel is van die seëvierende Israeliete (vs 20)! Die eenheid Jos 10:16-27 verskil van die voorafgaande eenheid in die sin dat JHWH slegs in die woorde van die karakter Josua op die toneel gebring word (vs 19, 25), terwyl JHWH in vs 1-15 sprekend en handelend op die toneel gebring word deur die verteller (vs 8, 10a, 12-14).

In Jos 10:28-39 verskyn, soos reeds aangetoon, die name van stede wat nie ooreenkom met dié in vs 1-15 nie. Volgens Butler (1983:119) is die onverwagse voorkoms van die naam Libna in die lys van vyf stede 'n bewys daarvan dat ons met 
onafhanklike tradisies te doen het in vs 1-27 en 28-39 (vgl ook Miller \& Tucker 1974:88 vir 'n soortgelyke standpunt). Die kommentaar van Boling in dié verband is ook van belang (1982:291):

It is in fact impossible to harmonize fully the description of the coalition (vv $1-5)$ with the account of the campaign in the south ( $v v 28-39)$. This is due in no small measure to the way in which an ancient editor chose to work (or was obliged to work) with preformed narrative units. It is thus not surprising that essentially the same history might be reflected with considerable differences of detail and emphasis.

In Jos 10:28-39 kom 'n bepaalde patroonmatigheid voor wat verwantskap toon met konvensionele oorlogverslae in die Ou Nabye Ooste (vgl Rowlett 1996:71-120). Die herhaling van terme en uitdrukkings soos החרים (vs 28, 35, 37 en 39), לא ה שאיר שריד (vs 28, 30, 33, 37 en 39), כאשר עשה ל (vs 28, 30, 32, 35, 37 en 39) het net een doel en dit is om te beklemtoon dat Josua die banvloek toegepas het soos wat dit voorgeskryf word in die Deuteronomistiese wet (vgl Deut 20:16). Dieselfde outeur wat verantwoordelik is vir hierdie herhalende patroon, was waarskynlik ook verantwoordelik vir die invoeging van die woorde "soos wat hy met Jerigo en haar koning gedoen het, so het hy met Ai en haar koning gedoen" in die raamvertelling aan die begin van die hoofstuk (vs 1; Noth [1971:63] is ook oortuig daarvan dat dit 'n latere toevoeging is). Die outeur van vs 28-39 skryf die oorwinnings oor die stede in die eerste twee gevalle toe aan JHWH (vs 30 en 32) en dit is waarskynlik die versweë veronderstelling in al die ander gevalle. Die fokus is egter nie daarop nie, maar op die nougesette voltrekking van die banvloek oor die stede se inwoners deur Josua.

Jos 10:40-43 is ' $\mathrm{n}$ afsluitende resumé van die vertelling. Dit is egter ook meer as dit: Die oorwinning oor ses stede word ' $n$ inbesitname van die hele suide van die beloofde land. In hierdie idealistiese voorstelling word die wesenlike van die voorafgaande eenhede goed saamgevat, naamlik dat Josua in sy suksesvolle veldtog die banvloek nougeset voltrek het volgens die bevel van JHWH (vs 40) en dat JHWH die oorwinnings moontlik gemaak het (vs 42). 
Dit is duidelik dat Jos 10 saamgestel is uit eenhede wat oorspronklik onafhanklike oorlewering (mondeling of skriftelik) verteenwoordig. Die relatiewe kronologie van die eenhede kan vanselfsprekend nie met absolute sekerheid vasgestel word nie. Dit lyk egter waarskynlik dat die oudste eenheid die raamvertelling van Josua se veldtog teen die vyf konings was. Twee ander oorlewerings is hier bygevoeg, naamlik die oorlewering oor vyf konings wat by Makkeda in die grot geskuil en later daar begrawe is, en die oorlewering oor die inname van die stede in die suidelike heuwelland van Juda. Hierdie oorlewerings het die moontlikheid gebied om 'n vertelling te skep waarin Josua as die ideaal-figuur na vore kom. Die byeenbring van die eenhede is waarskynlik gedoen deur die outeur(s) wat die resumé aan die einde geskryf het. Hy (hulle) was ook verantwoordelik vir die invoegings in die raamvertelling aan die begin waarin JHWH as die eintlike oorwinnaar na vore gebring word. Ek meen dit is nie toevallig dat die woorde כי יהוה אלהי ישראל נלחם לישראל in vs 14 en die woorde כי יהוה נלחם לישראל vs 42 voorkom nie. Daarmee sê die outeur(s) as 't ware wat die doel van die vertelling is, naamlik om aan te toon dat die verowering van die gebied van Juda alleen moontlik was deur die wonderbaarlike ingryping en hulp van JHWH. Die oorspronklike heldesage oor Josua is daarmee in 'n wondervertelling omskep.

Dat hierdie outeur(s) uit Deuteronomistiese kringe kom, staan vir my bo alle twyfel. Die teologiese kommentaar wat in die heldesage oor Josua (Jos 10:1-15) ingevoeg is, bring presies tot uitdrukking wat die priester as gevolmagtigde van JHWH volgens Deuteronomium 20:3-4 vir die volk moes sê voordat hulle in 'n geveg met hulle vyande betrokke raak, naamlik: "Moenie bewe nie, moenie bang wees nie, moenie vreesbevange word nie, moenie vir hulle skrik nie. JHWH julle God gaan saam met julle om vir julle teen julle vyande te veg, om julle die oorwinning te laat behaal." Die volgende opmerking van Fritz (1994:15) is ook hier ter sake:

Neben der konsequenten Schilderung Josuas als des Führers bei der Landnahme und der Verteilung des Landes zeigt das Buch noch weitere Elemente bewußter Gestaltung, die auf eine starke Theologisierung der Landnahme zielen. Die Eroberung des Landes steht völlig unter der deuteronomistischen Konzeption des Heiligen Krieges .... Eigentlich führt 
Jahwe den Krieg für Israel und gibt den Sieg über die Feinde, wie 6,2; 10,8;

11,6 ausdrücklich betont wird.

Die idealisering van die Josua-karakter, wat diensbaar gemaak word aan die teologiese konstruk dat die inname en besit van die land alleen moontlik is deur die wonderbaarlike ingryping van JHWH, was klaarblyklik die maatstaf waarvolgens die vertelmateriaal in die verhaal van Josua georden en van kommentaar voorsien is. Die vraag na die volledige redaksiegeskiedenis van Josua 10 kan uit die aard van die saak nie in hierdie artikel ondersoek word nie. Dit is moontlik dat 'n bestaande basisvertelling uitgebrei is deur die byvoeging van ander tradisies of oorgelewerde materiaal en dat dít van teologiese kommentaar voorsien is. Daar is ook ander modelle waarmee die redaksiegeskiedenis van die boek Josua en daarmee saam Jos 10, verklaar kan word. Wat egter wel duidelik is, is dat van die oorlewerings wat in Jos 10 opgeneem is, reeds soveel gesag gehad het dat dit nie gewysig is om die oneffenhede uit te stryk nie. In 'n boek wat nie bedoel is om gewone geskiedenis te beskryf nie, maar wat 'n teologiese en ideologiese argument voer aan die hand van ou tradisies en by wyse van 'n vertelling oor die inname van die land, hóéf alles ook nie presies logies te klop nie. Die motiewe van heilige oorlog en die vernietiging van die nie-Israeliete as voorwaarde vir die bewoning van die land, is in die laaste instansie geweef op die teologies-ideologiese stramien van die land as gawe van JHWH. Wondervertellings waarin JHWH en nie mense of natuurlike gebeure nie, die land aan die Israeliete gee, legitimeer nie net die aansprake op die land nie, maar plaas ook die hele saak van die besit van die land buite debat. Israel het nie toevallig in besit van die land gekom nie, en daarom kan hy dit nie deur historiese gebeure soos die inname van die land deur die Assiriese of Babiloniese wêreldmagte, verloor nie. Dít is die konteks waarbinne die verwysing na die son en maan wat stilgestaan het, verstaan moet word.

\section{JOSUA 10:12-14 AS WONDERVERTELLING}

Dit is duidelik dat Jos 12b-13a 'n poëtiese fragment is:

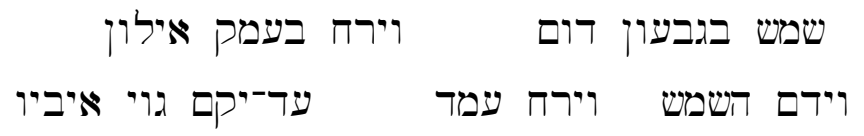


Dit hou belangrike implikasies in vir die interpretasie daarvan. In die eerste plek is die volledige gedig (of lied) waaruit hierdie fragment kom, nie meer beskikbaar nie. Dit beteken dat die oorspronklike konteks verlore is, en dat enige poging om dit te rekonstrueer, blote spekulasie is. Dit is nie eens seker dat die gedig waaruit die fragment geneem is, na 'n historiese veldslag verwys nie. In die tweede plek is dit poësie waarin van metaforiese taal gebruik gemaak word. In sy oorspronklike konteks kon dit metaforiese taal wees met 'n mitiese agtergrond waarmee die mag van JHWH of 'n ander god of selfs ' $n$ heldefiguur besing is. Die feit is dat die oorspronklike konteks van die poësie-fragment vir altyd verlore is (vgl Butler 1983:116).

Die nuwe konteks waarbinne hierdie fragment geplaas is, het hom in elk geval van sy moontlike mitiese agtergrond gestroop. Die outeur wat die teologiese kommentaar in Jos 10:1-15 geskryf het, het die fragment diensbaar gemaak aan sy doel, naamlik om aan te toon dat die oorwinning oor die vyande alleen deur JHWH moontlik gemaak is. En vir dié doel het hy die fragment letterlik geïnterpreteer, soos duidelik blyk uit die kommentaar wat hy daarby skryf in vs 13b-14. Die kommentaar wat in $13 \mathrm{~b}$ en 14 gebied word, het die poëties-metaforiese taal in vs $12 \mathrm{~b}$ en 13a letterlik as 'n stilstaan van die son geïnterpreteer, en wel so dat die son vir 'n dag lank nie ondergegaan het nie. Of soos Noth (1971:65) dit stel: 'Die Aussage vom 'Stehenbleiben' der Sonne (und des Mondes) will nach der Meinung des 'Sammlers' doch wohl ganz wörtlich verstanden werden im Sinne eines unerhörten Wunders." Die inhoud van die fragment word trouens nie net letterlik geïnterpreteer nie, maar selfs ook van enkele verduidelikende detail voorsien, soos dat die son in die middel van die lug bly staan het en nie haastig was om onder te gaan nie. Indien dit, soos sommige eksegete veronderstel (bv Boling 1982:284), in die fragment gaan oor 'n gunstige konstellasie van twee hemelliggame, naamlik die son en die maan, weerspreek die outeur wat die kommentaar geskryf het dit in elk geval met sy verduideliking dat die son in die middel van die lug bly staan het, aangesien die maan dan nie sigbaar is nie (vgl Margalit 1992:479). Die volgende opmerking van Fritz (1994:111) sou dalk van toepassing kon wees op 'n vroeëre stadium van die redaksionele geskiedenis van die fragment, maar is nie van toepassing in die huidige konteks nie: Vorausgesetzt ist dabei, daß beide Gestirne in einer bestimmten Konstellation sich günstig auf das Geschick auswirken; ihr Verharren in dieser Stellung entscheidet das 
Kampfgeschehen. Sonne und Mond greifen zugunsten Israels in die Schlacht ein, indem sie ihre bestimmende Position bewahren.

Fritz (1994:112) het egter wel gelyk wanneer hy, wat die funksie van die fragment in sy nuwe konteks betref, sê: "Die kosmische Dimension der aufgenommenen Verse wird so im Sinne einer realen Gegebenheit umgedeutet. ... Nicht mehr die Kombination von solarem und lunearem Einfluֵ bedingt den Sieg, sondern Jahwe allein kämpft für Israel."

Die outeur wat hierdie fragment in die Josua-vertelling opgeneem het, het dit beslis nie gedoen vanuit astrologiese oorwegings of oortuigings nie. Indien die fragment opgeneem sou wees om daarmee te suggereer dat sterrekonstellasies verantwoordelik was vir die oorwinning van die Israeliete, sou dit lynreg ingaan teen die teologiese doel wat die outeur met die vertelling gehad het, naamlik dat JHWH, en Hy alleen, verantwoordelik was vir die oorwinning wat Josua op die koalisie van vyf konings behaal het. Fritz het gelyk wanneer hy sê dat 'n veldslag in die fragment veronderstel word. Hy het ook gelyk wanneer hy sê dat die verwysing na Gibeon in die poëtiese fragment waarskynlik die rede was vir die opname daarvan in die vertelling oor die veldslag by Gibeon (Fritz 1994:111). Maar dit is sover as wat ons kan gaan. Die feit dat dit 'n fragment is, dat die oorspronklike konteks van die fragment verlore is en dat dit tans ingebed is in 'n nuwe konteks waarin dit gaan oor die oorwinning wat JHWH gegee het, behoort die eksegeet daarvan te weerhou om te spekuleer oor natuurverskynsels wat aanleiding sou kon gee tot die ontstaan van die gedig waaruit die fragment kom, of oor die mitiese agtergrond van die verwysings in die fragment.

Daar is vroeg reeds deur kommentatore geargumenteer dat die lied van Debora in Rigters 5 goeie vergelykingsmateriaal bied vir die verstaan van Jos 10:12b-13a (vgl bv Noth 1971:65; ook Fritz 112). Daar staan immers in die lied van Debora (Nuwe Afrikaanse Vertaling, Rigters 5:4-5, 20-21):

Toe U uit Seïr gekom het, Here, toe $\mathrm{U}$ uit die veld van Edom opgetrek het, het die aarde gebewe, het die hemel reën gegee: die wolke het strome water gegee. 
Die berge het weggesmelt voor die Here, voor Hom uit Sinai, voor die Here die God van Israel....

Uit die hemel het die sterre geveg, uit hulle bane het hulle teen Sisera geveg. Die Kisonrivier het die vyand meegesleur, die Kisonrivier, die rivier uit die voortyd.

Veral dié deel waarin dit gaan oor die hemelliggame wat aan die stryd deelgeneem het, word as goeie vergelykingsmateriaal beskou. Die lied van Debora en die fragment in Josua 10:12b-13a funksioneer egter op verskillende vlakke. In die geval van die lied van Debora het ons ' $n$ volledige gedig waarin klaarblyklike mitiese verwysings voorkom. Dit word buitendien ook begelei deur 'n afsonderlike vertelling oor die gebeure wat in die gedig aan die orde is. Alhoewel die vertelling in Rigters 4 legendaries van aard is en die gedig in Rigters 5 mitiese taal bevat, is dit nie 'n wondervertelling nie. Jos 10:12-14 is juis 'n wondervertelling wat die waarskynlik oorspronklike mitiese verwysings "ontmitologiseer" het deur dit te historiseer. Om dié rede kan daar byvoorbeeld nie met kommentatore soos Butler (1983:113) saamgestem word wanneer Jos 10:12-14 in die konteks waarin dit tans staan, as dieselfde soort literatuur as Rigters 5 beskou word nie.

Eksodus 14 en 15 bied egter wel goeie vergelykingsmateriaal. Houston (1997:347-354) wys daarop dat die poëtiese teks in Eksodus 15:1b-18 nie 'n verwysing na die Israeliete se tog deur die Rietsee bevat nie. Dit verwys slegs na die vernietiging van die Egiptiese leër deur 'n geweldige golf'. Hieruit lei hy af dat die poëtiese teks in Eksodus 15 ouer is as die prosavertelling in Eksodus 14. Hy argumenteer op goeie gronde dat dit andersins onverklaarbaar is dat die wesenlikste element van die vertelling in Eksodus 14 en alle latere tekste, naamlik dat die Israeliete droogvoets deur die see getrek het, uitgelaat sou word in 'n lied wat juis veronderstel is om die gebeure waarna die prosavertelling verwys, te besing. Ter ondersteuning van hierdie standpunt van Houston kan daarop gewys word dat die outeur wat die poëtiese teks in sy vertelling opgeneem het, dit klaarblyklik nodig gevind het om ná die duidelike slot van die lied (vs

\footnotetext{
${ }^{5}$ Houston laat die moontlikheid oop dat dit 'n poëtiese weergawe is van 'n historiese gebeure waarin die skepe van Egipte in 'n storm op see vernietig is.
} 
18), 'n deel by te voeg waarin dit duidelik gestel word dat die Israeliete droogvoets deur die see getrek het ( $v g 1$ vs 19). Houston kom tot die konklusie dat die vertelling 'n letterlike interpretasie en uitbreiding van die metaforiese (hy noem dit "figurative") taal van die stuk poësie is. Hy vat die saak soos volg saam (1997:353):

It is unnecessary to appeal to misunderstanding to explain the way in which the Song [Eksodus 15] has thus been interpreted, particularly a misunderstanding of a word several verses further on; and the literal understanding of the standing waters is not simply due to lack of imagination. Rather, the panels of the Song have consciously been taken apart, and their meaning pressed to the utmost, in order to accommodate the extra motif of the safe passage of the Israelites, to heighten the miracle and to give a role to Moses in the story.

Houston is klaarblyklik oortuig daarvan dat dieselfde soort proses hom in Jos 10 afgespeel het met die aanhaling uit die ספר הישר, of soos hy dit terloops stel: "In Ex 14 , as in Jos 10, the prose is developed from the verse, and creates out of it a fresh narrative rooted in the words of the verse" (Houston 1997:354).

Die prosagedeeltes in Eksodus 14 is net soos die prosagedeeltes in Jos 10:12-14 bedoel om 'n wondervertelling te wees. Dit is opmerklik dat juis in hierdie twee gevalle die metaforiese taal in poëtiese tekste letterlik geïnterpreteer is en dat mitiese spreekwyses gehistoriseer en so "ontmitologiseer" is, terwyl dit nie die geval is in Rigters 4 en 5 nie. Dele van die metaforiese taal in Rigters 5 kan sekerlik ook letterlik geïnterpreteer word. Dit is egter nie gedoen nie, klaarblyklik omdat dit in die begeleidende prosa-eenheid nie oor ' $n$ wondervertelling gaan nie. Die vraag of die letterlike interpretasie en daarmee die historisering van mitiese taal telkens net in wondervertellings voorkom, kan nie in hierdie artikel aandag kry nie, en sal verder ondersoek moet word.

\section{SAMEVATTENDE OPMERKINGS}

Jos 10 beskryf in sy huidige gestalte die inname van die suidelike deel van die land deur Josua na die intog. Die hoofstuk is saamgestel uit drie oorspronklik onafhanklike 
tradisies wat van kommentaar voorsien is. As genre ('n verslag oor veldslae) toon die perikoop ooreenkomste met soortgelyke beskrywings in ander Ou Nabye Oosterse literatuur. Dit verskil egter van hierdie verwante literatuur in dié opsig dat die fokus nie die eer van die koning of aanvoerder is nie (Nelson 1997:139), maar die wonderbaarlike ingryping van JHWH. Hierdie ingryping van JHWH word nie net by wyse van inligting deur die verteller gekommunikeer nie ( $\mathrm{vgl}$ vs $8,14 \mathrm{~b}, 42$ ), maar veral ook deur twee wondervertellings, naamlik die haelstorm wat die vyande gedood het (vs 11) en die verlengde dag (vs 12b-14). Die wondervertelling oor die verlengde dag kan teruggevoer word na die letterlike interpretasie van die metaforiese taal in 'n poëtiese fragment waarvan die oorspronklike konteks vir ons verlore is.

Die bedoeling van die vertelling in Jos 10 is klaarblyklik nie om historiese gebeure weer te gee nie, maar om aan die hand van oorgelewerde tradisies die leser onder die indruk te bring van JHWH se ingryping ter wille van sy volk. Die wyse waarop die ingryping van JHWH beskryf word wil die leser oorhaal tot vertroue in hierdie almagtige God wat die onmoontlike moontlik maak en sy beloftes aan sy volk nakom sonder dat mense werklik 'n aandeel daarin het. In die vertelling word Josua, op wie se versoek JHWH gereageer het, as ideaal-figuur voorgehou: Iemand wat JHWH vertrou, maar belangriker nog, wat aan Hom gehoorsaam is en sy opdragte uitvoer.

\section{TEN SLOTTE}

Ek dra graag hierdie artikel op aan drie vorige kollegas:

Professor Wouter van Wyk het vir my die deure na die Ou Testament oopgemaak. Hy het my die Hebreeuse alfabet en grammatika en die liefde vir die taal geleer. Hy het my ook geleer om die Hebreeuse teks van die Ou Testament ernstig te neem maar terselfdertyd kritiese vrae te vra. Daarvoor sal ek hom my lewe lank dankbaar bly.

Wally da Silva sal ek altyd as vriend onthou. Vir 'n volle veertig jaar het hierdie vriendskap geduur. Dié simboliese Ou-Testamentiese voltal jare was egter nog te min, en sy ontydige dood het iets kosbaar uit my lewe weggeneem. Ek eer sy nagedagtenis.

Die verbintenis met Louis Bezuidenhout het oor 'n baie korter tyd gestrek. Ek sal hom onthou as iemand met groot akademiese potensiaal. Hy is nog jonk en sal hopelik, 
al is hy nie meer voltyds in 'n akademiese pos nie, nog steeds 'n bydrae tot die vakgebied Ou-Testamentiese wetenskap kan maak.

\section{Literatuurverwysings}

Beek, M A 1981. Jozua. Nijkerk: G F Callenbach.

Boling, R G 1982. Joshua: A new translation with notes and commentary. New York: Doubleday (The Anchor Bible).

Butler, T C 1983. Joshua. Waco:Word Books. (Word Biblical Commentary.)

Fritz, V 1994. Das Buch Josua. Tübingen J C B Mohr. (HAT.)

Görg, M 1991. Josua. Würzburg: Echter. (Neue Echter Bibel.)

Gray, J 1967. Joshua, Judges and Ruth. London: Thomas Nelson.

Hertzberg, H W 1973. Die BücherJosua, Richter, Ruth. Göttingen: Vandenhoeck \& Ruprecht.

Houston, W J 1997. Misunderstanding or midrash? The prose appropriation of poetic material in the Hebrew Bible. ZAW 109, 342-355.

Kruger, H A J 1999. Sun and moon grinding to a halt: Exegetical remarks on Joshua 10:9-14 and related texts in Judges. HTS 55(4), 1077-1097.

Kruger, H A J 2000. Sun and moon marking time: A cursory survey of exegetical possibilities in Joshua 10:9-14. JNLS 26(1), 137-152.

Margalit, B 1992. The day the sun did not stand still: A new look at Joshua X 8-15. VT XLII(4), 465-491.

Miller, J M \& Tucker, G M 1974. The book of Joshua. Cambridge: University Press.

Nelson, R D 1997. Joshua: A commentary. Louisville:Westminster John Knox.

Noth, M 1971. Das Buch Josua. Tübingen: J C B Mohr.

Rowlett, L L 1996. Joshua and the rhetoric of violence. Sheffield: Academic Press. (JSOT Supplement 226.)

Soggin, J A 1972. Joshua: A commentary. London: SCM.

Steuernagel, C 1923. Das Buch Josua. Göttingen: Vandenhoeck \& Ruprecht. 